\title{
Social capital and knowledge sharing in the public sector
}

\author{
Ha Minh Tri ${ }^{1 *}$, Doan Bao Son ${ }^{2}$ \\ ${ }^{1}$ International University, Vietnam National University Ho Chi Minh City, Vietnam \\ ${ }^{2}$ Faculty of Aeronautical Electronics - Telecommunications, Vietnam Aviation Academy, Vietnam \\ *Corresponding author: hmtri@hcmiu.edu.vn
}

\begin{tabular}{|c|c|}
\hline ARTICLE INFO & ABSTRACT \\
\hline $\begin{array}{l}\text { DOI:10.46223/HCMCOUJS. } \\
\text { soci.en.11.1.1903.2021 }\end{array}$ & $\begin{array}{l}\text { This research proposes and validates a model } \\
\text { hypothesizing the relationships between social capital and } \\
\text { knowledge sharing in the public sector. We employed a survey } \\
\text { design using a questionnaire to collect data utilizing a convenient } \\
\text { sampling method. The study gathered } 389 \text { questionnaires from } \\
\text { civil servants and officials working in departments and agencies } \\
\text { in the public sector in Tien Giang province. The research }\end{array}$ \\
\hline Received: May $5^{\text {th }}, 2021$ & hypotheses were developed and validated using the Structura \\
\hline Revised: June $6^{\text {th }}, 2021$ & Model Modeling (SEM) approach. The research results show tha \\
\hline Accepted: June $12^{\text {th }}, 2021$ & $\begin{array}{l}\text { all hypothesized relationships were confirmed except the link } \\
\text { between structural social capital and tacit knowledge sharing. } \\
\text { Our study can be considered a pioneering study to investigate the } \\
\text { influence of social capital on both tacit knowledge sharing and } \\
\text { explicit knowledge sharing in the public sector. This work also } \\
\text { enriches the growing body of knowledge regarding social capital }\end{array}$ \\
\hline $\begin{array}{l}\text { Keywords: } \\
\text { explicit knowledge sharing; } \\
\text { public sector; social capital; tac }\end{array}$ & $\begin{array}{l}\text { and knowledge sharing in the public sector. Our research als } \\
\text { offers suggestions to leaders in the public sector concernin } \\
\text { relevant measures and policies that enable employees to shar } \\
\text { knowledge by promoting social capital. }\end{array}$ \\
\hline
\end{tabular}

\section{Introduction}

Over the last few years, public and private organizations have shown increased interest in managing knowledge and human resource. Knowledge sharing is increasingly important, not only as a means to obtaining personal benefits but also as a vehicle for improving the performance of both individuals and organizations (Kim \& Lee, 2005). While there are widely recognized agreement that there are various ways that societies can gain knowledge, those communities that leverage social capital are acknowledged as the main vehicles by which this knowledge is made available (Chow \& Chan, 2008; Kim \& Lee, 2010). Furthermore, several key factors influencing knowledge sharing and creation include social dynamics that stem from each individual and group's interpersonal and group relationships (Van den Hooff \& Huysman, 2009).

Studies on social capital and knowledge sharing have investigated the influence of social networks and shared goals on knowledge sharing attitudes. This indirect effect on knowledge sharing intention has been documented by researchers like Chow and Chan (2008), who assert that social networks and goals have a substantial impact on knowledge sharing attitudes. Ganguly, Talukdar, and Chatterjee (2019) found that social capital (both cognitive and relational) are important prerequisites for sharing tacit knowledge, impacting organizational innovation capability. Hau, Kim, Lee, and Kim (2013) argue that social capital affects the intent 
to disseminate explicit knowledge and tacit knowledge (TN). Zaqout and Abbas (2012) demonstrate the role of trust and social networks in promoting explicit knowledge and $\mathrm{TN}$ exchange as well as in developing tacit knowledge and improving work performance.

It is critical to discern the various influences on employees' desire to disseminate knowledge, which aids in enhancing the sharing of information between public-sector employees and agencies. Since there is so much research about organizational knowledge sharing, some of the variables may influence knowledge sharing in organizations. However, the majority of studies have examined knowledge sharing in the private sector. To date, there are limited studies that have examined knowledge sharing in the public sector (Amayah, 2013). Public organizations and knowledge-based organizations are known as public-sector organizations today (Willem \& Buelens, 2007). Firms in the private sector, as well as government agencies, must therefore see that information is as critical to their organizations as it is to the businesses in the private sector (Willem \& Buelens, 2007). To meet more demanding competition for resources and services, public organizations are challenged now more than ever before (Luen \& Al-Hawamdeh, 2001). The importance of developing processes to improve knowledge sharing cannot be overstated: These processes will enable current employees to learn from and benefit from the knowledge and experience of their senior colleagues prior to retirement (Amayah, 2013).

Knowledge management in the public sector in Vietnam tends to move slower than in the private sector. Specifically, public organizations do not have effective mechanisms and solutions to encourage civil servants and public employees to create and share knowledge. They turn each individual's ability into the organization's knowledge and the civil service to bring advantages and operational performance to them. Furthermore, no study has looked specifically at social capital dimensions and knowledge sharing relationships, including explicit knowledge sharing and tacit knowledge sharing in the public sector. Such a comprehensive examination of these relationships would address that research gap. The specific objective of this work is to study the link between the social capital dimensions and knowledge sharing among individual members in the public sector.

\section{Literature review and hypotheses development}

Social capital is effectively a theory appreciating 'it's not what you know, but who you know' and developed on the strength of weak ties, as defined by M. S. Granovetter (1973). According to this theory, resources accessed through weak ties will be more valuable than those accessed through stronger relational ones. This was explained by developing strong ties between similar individuals who, by definition, would have similar contacts and thus access to similar resources.

Nahapiet and Ghoshal (1998) were instrumental in establishing social capital as a valid construct within management research, proposing a model of social capital composed of a number of components that could be used to explain both micro- and macro-level behavior of individuals and groups. The model classified the concept into three distinct components: cognitive, structural, and relational, all of which will be discussed in greater detail in the following sections. While the preceding emphasizes that social capital theory's primary purpose was to provide insight into obtaining valuable resources, it may also serve as a control mechanism and help explain how communities behave.

\subsection{Social capital dimensions}

Social capital is defined as "the sum of the actual and potential resources embedded within, available through, and derived from the network of relationships possessed by an 
individual or social unit" (Nahapiet \& Ghoshal, 1998, p. 243). Adler and Kwon (2002) conceptually constructed a model of social capital that classifies the various forms, origins, and effects of the concept. They defined social capital as "the goodwill available to individuals or groups whose source is found in the structure and content of a person's social relations" (p. 23). Furthermore, social capital can be categorized into three interrelated components: structural, relational, and cognitive (Nahapiet \& Ghoshal, 1998).

Social capital can be defined as the number of networks a person or group maintains or the network composition of an organization. It is viewed through a network's size, the number of network ties, and stability (Inkpen \& Tsang, 2005). Cognitive social capital is defined as the collective knowledge and awareness possessed by people that allows them to form an agreement and identify patterns and patterns across participants (Nahapiet \& Ghoshal, 1998). For one facet of the dimension, we have mutually agreed upon goals and a network culture that members participate in (Inkpen \& Tsang, 2005). While in relational social capital, we focus on the way actors' personal ties are connected to relational outcomes of interactions, we are interested in structural results of interactions. Previous research, for example, that of Hau et al. (2013), has shown that the significant role of social ties, shared goals, and social trust in social capital are corroborated by further analysis.

\subsubsection{Structural social capital and relational social capital}

A relationship (as opposed to the material) holds structural social capital, which is presented in social interaction ties. These ties help increase trust, called relational social capital (Tsai \& Ghosal, 1998). Research conducted previously has asserted that social interaction appears to be the foundational building block for forming trusting relationships (M. Granovetter, 1985). The intimate connection grows between the two actors as they divulge personal information over time, and as this happens, the actors will discern each other as trustworthy (Gabarro, 1978). Actors can learn about and relate to one another through frequent and close social interactions, obtain relevant information, and collectively form a common viewpoint. As a result, when an actor occupies a central position in a social interaction network, he is more likely to be perceived as trustworthy by the network's other actors (Tsai \& Ghosal, 1998). Therefore, it is relevant to formulate the hypothesis as below.

\section{H1: Structural social capital will be positively related to relational social capital}

\subsubsection{Cognitive social capital and structural social capital}

The relationship between structural social capital and cognitive social capital is predicated on the premise that social interaction is critical in configuring common goals and values and enabling an organization to communicate these goals and values (Tsai \& Ghosal, 1998). To study cognitive accuracy in the minds of individuals, Krackhardt (1990) performed a comprehensive investigation of the entire organizational social structure and found the structure of members' social interactions has an impact on the formation of a shared vision. Many aspects of organizational socialization (such as informal social interaction) have been described in terms of organizational values in the literature (Van Maanen \& Schein, 1979). Actors understand and adopt the language, codes, values, and practices of their organizations as a result of acting in accordance with the concepts that arise from social interaction. However, these actors could also generate new values and new perspectives that they have in common as well as entirely new visions relying on their shared interests and understandings. Units within a multi-building firm may have various interests and goals, but those goals and interests may differ from those of other units within the corporation. An individual member of a unit can have a collective orientation that aligns with the goals and plans they pursue (Tsai \& Ghosal, 1998). Accordingly, we propose: 


\section{H2: Structural social capital will be positively related to cognitive social capital}

\subsubsection{Relational social capital and cognitive social capital}

By supporting and enhancing a group's shared values and showing a clear common vision, the cognitive dimensions of social capital can encourage people to form trusting relationships (Tsai \& Ghosal, 1998). The kind of relationship one develops with someone who trusts you indicates that "Common goals and values have brought and kept them together" (Barher, 1983, p. 21). In the view of Ouchi (1980, p. 138), "Common values and beliefs provide the harmony of interests that erase the possibility of opportunistic behavior". As Sitkin and Roth (1993) asserted, there is a positive relationship between trusting relationships and value congruence; that is, people's values and the organization's values are similar. Using a cooperative framework and goal, individuals within the organization tend to trust each other, as they can expect that everyone is working toward a cooperative framework (Tsai \& Ghosal, 1998). Therefore, it is appropriate to formulate the hypothesis as follows.

\section{H3: Cognitive social capital will be positively related to relational social capital}

\subsection{Social capital and knowledge sharing}

Structural social capital consists of relationships, density, configuration, and network relevance (Nahapiet \& Ghosal, 1998). Network relationships allow access to resources embedded in social relationships, and knowledge is by far the most precious asset embedded in that relationship (Ganguly et al., 2019). Employees in organizations will establish many face-toface relationships and social networks that increase the opportunities for those connections. Employees will then be more likely to be willing to share skills and thoughts with those with whom they have a special relationship (Chow \& Chan, 2008). While creating and sharing knowledge in an organization is correlated with the social network structure, the building of a social network is the process of the knowledge creation and sharing process (Borgatti \& Cross, 2003). Because of the close relationships and network structure of the structural social capital, actors can more easily communicate with one another, thus increasing the flow of knowledge throughout the entire network (Reagans \& McEvily, 2003). In particular, strong social networks with a high level of intensity, in which participants have frequent and close interactions, will help promote the spread of tacit knowledge (Ganguly et al., 2019).

As a result, social interactions are crucial to the successful tacit knowledge-sharing process (Nonaka, 1994). In the course of the conversion and creation of knowledge in organizations, information is disseminated through "socialization", which necessitates numerous social interactions between employees (Nonaka, 1994). However, compared to explicit knowledge, which is mostly transferred or shared through "combination," which depends more on transactional interactions, social interactions have very little to do with it (Hau et al., 2013). Based on these arguments, it is reasonable to formulate the hypotheses as below.

\section{H4: Structural social capital is positively related to explicit knowledge sharing}

\section{H5: Structural social capital is positively related to tacit knowledge sharing}

The relational social capital represented by trust and credibility is essential for a thick social network structure that promotes knowledge acquisition and assimilation (Ganguly et al., 2019). Trust among organizational members is a factor that improves interactive relationships and promotes successful knowledge sharing (Chow \& Chan, 2008). Trusting others and allowing others to trust are essential for knowledge-sharing initiatives. If the organization members have trusted relationships, they are willing to allow colleagues to access their resources. Trust also increases the quality of knowledge sharing (Zaqout \& Abbas, 2012). Inkpen and Tsang (2005) 
assert that trust is essential to the coherence of relationships between parties. It acts as a check on opportunistic behavior and provides the basis for free knowledge exchange. In addition, interpersonal trust will promote tacit knowledge sharing (Foos, Schum, \& Rothenberg, 2006).

By establishing a common identity that facilitates the free exchange of knowledge and reduces the cost of learning, relational embeddedness eliminates barriers and promotes learning (Dyer \& Nobeoka, 2000). Trust contributes to knowledge sharing by instilling a sense of security that the knowledge will not be used for purposes other than those for which it was intended. Operating systems that are common allows for the implementation of a shared communication protocol, which promotes the flow of information. To aid in clarifying and controlling information, relational nexus performs three key roles in knowledge sharing: clarification, control, and motivation (Dhanaraj, Lyles, Steensma, \& Tihanyi, 2004). Trust can be conceptualized in two dimensions: benevolent trust and competence trust, according to Levin and Cross (2004). The empirical study conducted on this topic claims that perceived competency-based trust helps facilitate tacit knowledge sharing. In contrast, benevolence-based trust can facilitate both explicit knowledge sharing and tacit knowledge sharing. Their results suggest that relational social capital is crucial to forming dense social networks to act as a productive precursor of knowledge acquisition and assimilation (Ganguly et al., 2019). Therefore, it is appropriate to formulate hypotheses as follows.

\section{H6: Relational social capital is positively related to explicit knowledge sharing}

\section{H7: Relational social capital is positively related to tacit knowledge sharing}

Cognitive social capital includes the goals, vision, and values shared by members of the organization. When trying to discern knowledge to be gathered and evaluated, participants' shared goals, language, and understanding are influential (Kogut \& Zander, 1996). Similarly, Inkpen and Tsang (2005) assert that a common vision and a set of mutually agreed upon goals serve as a glue that motivates actors across an intra-corporate network to embrace and successfully integrate newly acquired knowledge. Social capital is comprised of various elements, all of which work together to shape how people behave. One of these elements is culture, which is defined as a shared set of values, beliefs, and norms. Together, these various elements mold how people behave cognitively (Wasko \& Faraj, 2005). Individuals exchanging tacit knowledge through exchange mechanisms related to socialization need a common understanding and experience, and a mode of knowledge transfer involves shared experiences and thinking processes (Nonaka, 1994).

Groups must have a common goal to foster mutual understanding and exchange of ideas. It's thus possible to consider goals shared by two or more people to be the powerful force that holds them together and encourages them to share their knowledge. A goal shared by all members of an organisation can be obtained through cooperation and knowledge sharing (Chow \& Chan, 2008). Therefore, it is relevant to formulate hypotheses as follows.

\section{H8: Cognitive social capital is significantly associated with explicit knowledge sharing \\ H9: Cognitive social capital is significantly associated with tacit knowledge sharing}

\subsection{Explicit knowledge sharing and tacit knowledge sharing}

Explicit knowledge is objective knowledge; in other words, it is written down and can be delivered to others, as well as made explicit using official avenues (Alavi \& Leidner, 2001). Explicit knowledge is widely available, and it can be found in several different formats, including files, library collections, and databases (Nonaka \& Takeuchi, 1995). However, it is difficult to precisely identify and quantify the extent of tacit knowledge, which is thought to be 
derived from experience and primarily in the minds of individuals (Hlupic, Pouloudi, \& Rzevski, 2002). It has also been described as casual, free-flowing, private, and mysterious, and compelling. The issue here is that tacit knowledge is nearly impossible to represent in words accurately, and this makes it extremely difficult to put it in databases (Zaqout \& Abbas, 2012).

Organizational knowledge creation entails creating new content or updating existing content in the organization's tacit knowledge and explicit knowledge (Pentland, 1995). Information is generated, shared, increased, enlarged, and substantiated in organizational settings by social and collaborative processes, as well as the individual's cognitive processes, such as thinking, pondering, and consideration (Nonaka, 1994). Nonaka (1994) suggested that the process of generating and creating knowledge can be categorized into four processes: socialization, externalization, combination, and internalization, with the addition of transferring knowledge between tacit knowledge and explicit knowledge. Externalization is the process of taking existing tacit knowledge and turning it into new explicit knowledge (e.g., articulation of best practices or lessons learned) (Reychav \& Weisberg, 2009). Because of this conversion, individuals are able to gain knowledge that, when expressed in terms of technical or academic data, is known as technical and educational documentation, such as manuals, documents, and patents (Nonaka, 1994).

Tacit knowledge is integrative, challenging to express, and inferable by action. It's finegrained, and it gives the explicit knowledge more meaning and understanding. Tacit knowledge explains how the whole is better than the sum of its parts. Tacit knowledge, in essence, gives sense to many of an organization's stated practices (Dhanaraj et al., 2004). Fundamentally, tacit knowledge refers to highly individualized information that is difficult to record or formalize (Nonaka, 1991). In addition, Hau et al. (2013) believe that sharing one's explicit knowledge takes less work than sharing one's tacit knowledge. A person who is eager to offer his or her tacit knowledge is undoubtedly willing to share his or her explicit knowledge (Hau et al., 2013). Tacit knowledge positively sharing promotes explicit knowledge sharing, according to Dhanaraj et al. (2004) and Chumg, Cooke, Fry, and Hung (2015). On the other hand, Reychav and Weisberg (2009) demonstrated that people who are eager to disclose their tacit knowledge are also likely to reveal their explicit knowledge. Thus, it is reasonable to propose a hypothesis as below.

H10: Tacit knowledge sharing is positively associated with explicit knowledge sharing

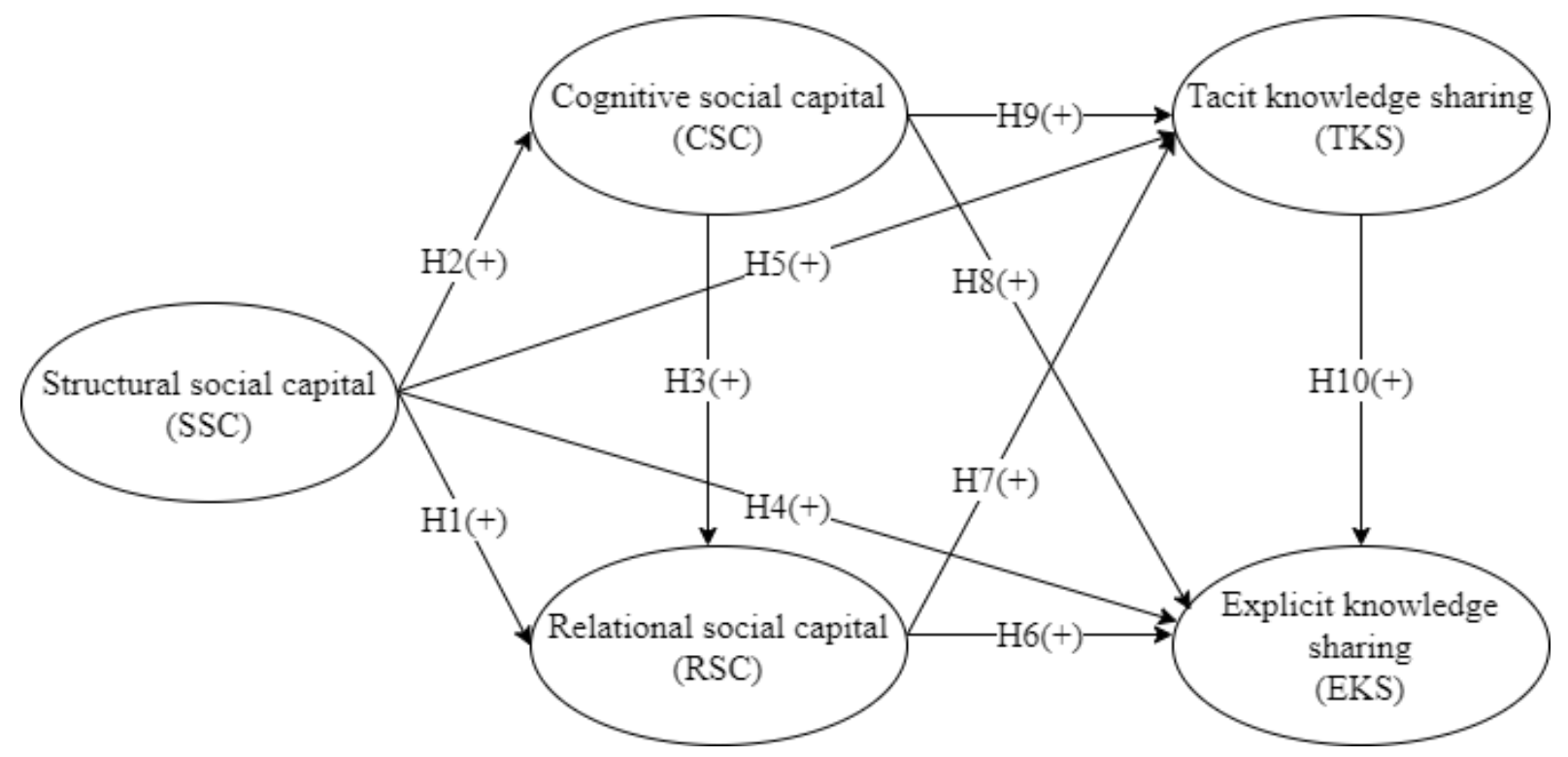

Figure 1. Hypothesized model 


\section{Methodology}

\subsection{Data collection and sampling}

This study adopts a survey design that uses a questionnaire to collect data. Respondents of this study were civil servants and public employees working in public departments in Tien Giang. Our study used a convenient sampling method to collect a sample size of 450 (Hair, Black, Babin, \& Anderson, 2014; Kline, 2015). Before data collection, a pre-test of the questionnaire was performed with a small group of respondents $(n=10)$ to ensure the wording, content as well as special or technical terminologies that could be difficult to understand for respondents. The pre-test results show that cognitive and structural social capital dimensions may cause confusion. Consequently, our questionnaire provides a detailed explanation of these two terms. Data collection took place between March and April of 2021. With 450 questionnaires distributed, 389 were returned, resulting in an 86.4 percent response rate.

\subsection{Measures}

Our study uses a five-point Likert scale, scoring from 1 denoting "strongly disagree" to 5 denoting "strongly agree" to measure observed variables. Measurement scales were adapted from validated literature. Specifically, both structural social capital and relational social capital include four items adapted from Chow and Chan (2008) and Nahapiet and Ghoshal (1998). Cognitive social capital includes four items adapted from Chow and Chan (2008), and Miller, Besser, and Malshe (2007). Explicit knowledge sharing and tacit knowledge sharing, including six items and seven items, respectively, were adapted from Reychav and Weisberg (2009) and Z. Wang and Wang (2012).

\section{Table 1}

Constructs and their responding measures

\begin{tabular}{|c|c|c|c|c|}
\hline \multicolumn{2}{|c|}{ Constructs and indicators } & Loading & AVE & $\mathbf{C R}$ \\
\hline \multicolumn{5}{|c|}{ 1. Structural social capital (SSC) } \\
\hline SSC1 & In general, I get along splendidly with my coworkers & 0.654 & \multirow{4}{*}{0.560} & \multirow{4}{*}{0.834} \\
\hline SSC2 & My coworkers are aware of the expertise I possess & 0.807 & & \\
\hline SSC3 & $\begin{array}{l}\text { I'm aware of which knowledge might be useful to which } \\
\text { coworker }\end{array}$ & 0.829 & & \\
\hline SSC4 & $\begin{array}{l}\text { I am confident that everyone in my department knows of } \\
\text { relevant knowledge that is available to them }\end{array}$ & 0.689 & & \\
\hline \multicolumn{5}{|c|}{ 2. Relational social capital (RSC) } \\
\hline $\mathrm{RSC1}$ & $\begin{array}{l}\text { My colleagues are my extended family, and I am very close to } \\
\text { them }\end{array}$ & 0.777 & \multirow{4}{*}{0.607} & \multirow{4}{*}{0.860} \\
\hline $\mathrm{RSC} 2$ & $\begin{array}{l}\text { My coworkers will always be there to help me if I am in } \\
\text { trouble }\end{array}$ & 0.687 & & \\
\hline $\mathrm{RSC} 3$ & My coworkers will help me if I do require assistance & 0.827 & & \\
\hline RSC4 & $\begin{array}{l}\text { I have total trust in my colleagues because I know they will } \\
\text { help me when I need it }\end{array}$ & 0.817 & & \\
\hline
\end{tabular}




\begin{tabular}{|c|c|c|c|c|}
\hline & Constructs and indicators & Loading & AVE & CR \\
\hline 3. Cog & nitive social capital (CSC) & & & \\
\hline CSC1 & $\begin{array}{l}\text { Every time I'm at work, my colleagues and I always come to } \\
\text { an agreement on what is critical in the workplace }\end{array}$ & 0.719 & & \\
\hline $\mathrm{CSC} 2$ & $\begin{array}{l}\text { My coworkers and I always get along well when it comes to } \\
\text { working goals and vision }\end{array}$ & 0.801 & & \\
\hline CSC3 & $\begin{array}{l}\text { My coworkers and I are never in a poor mood when working } \\
\text { toward the organisation' shared goals and missions }\end{array}$ & 0.822 & 0.014 & 0.804 \\
\hline CSC4 & $\begin{array}{l}\text { Personal socializing is something that I like to offer my } \\
\text { colleagues }\end{array}$ & 0.789 & & \\
\hline 4. Exp & licit knowledge sharing (EKS) & & & \\
\hline EKS1 & $\begin{array}{l}\text { My coworkers frequently make use of reports and official } \\
\text { documents that already exist for the purposes of sharing them }\end{array}$ & 0.733 & & \\
\hline EKS2 & $\begin{array}{l}\text { My coworkers routinely share reports and official papers that } \\
\text { they have prepared on their own }\end{array}$ & 0.790 & & \\
\hline EKS3 & $\begin{array}{l}\text { My coworkers routinely acquire reports and formal documents } \\
\text { from others }\end{array}$ & 0.811 & & \\
\hline EKS4 & $\begin{array}{l}\text { Knowledge-sharing strategies are regularly used to motivate } \\
\text { people in my organization }\end{array}$ & 0.856 & 0.000 & 0.90 \\
\hline EKS5 & $\begin{array}{l}\text { My coworkers are routinely given a variety of training and } \\
\text { development opportunities }\end{array}$ & 0.867 & & \\
\hline EKS6 & $\begin{array}{l}\text { My coworkers benefit from IT solutions that have been } \\
\text { invested in knowledge sharing }\end{array}$ & & & \\
\hline 5. Taci & t knowledge sharing (TKS) & & & \\
\hline TKS1 & $\begin{array}{l}\text { My coworkers routinely share their experience-based } \\
\text { expertise }\end{array}$ & 0.802 & & \\
\hline TKS2 & $\begin{array}{l}\text { My coworkers routinely gather information from others based } \\
\text { on their own experiences }\end{array}$ & 0.760 & & \\
\hline TKS3 & $\begin{array}{l}\text { My coworkers routinely communicate their know-where or } \\
\text { know-whom information with others }\end{array}$ & 0.777 & & \\
\hline TKS4 & $\begin{array}{l}\text { My coworkers routinely communicate their know-where or } \\
\text { know-whom information with others }\end{array}$ & 0.760 & 0.577 & 0.872 \\
\hline TKS5 & $\begin{array}{l}\text { My coworkers routinely share their expertise-based } \\
\text { knowledge }\end{array}$ & 0.696 & & \\
\hline TKS6 & $\begin{array}{l}\text { My coworkers routinely gather information from others } \\
\text { depending on their areas of expertise }\end{array}$ & & & \\
\hline TKS7 & $\begin{array}{l}\text { When it feels essential, my coworkers will share lessons } \\
\text { learned from previous failures }\end{array}$ & & & \\
\hline
\end{tabular}




\subsection{Data analysis}

Data analysis employs a two-step approach provided by Anderson and Gerbing (1988). Data is analyzed using IBM AMOS 24 (Arbuckle, 2016). The first step is to establish a measurement model to confirm a Confirmatory Factor Analysis (CFA) procedure. Tests of reliability and validity are performed to determine how reliable and valid the measurement model is. The next step is to evaluate a structural model by performing a path analysis to confirm a set of hypotheses.

\section{Empirical findings}

\subsection{Description of sample characteristics}

Table 2 depicts the demographic information of 389 respondents, including gender, age, educational level, and work experience.

\section{Table 2}

Characteristics of sample respondents

\begin{tabular}{|l|c|c|}
\hline \multicolumn{1}{|c|}{ Characteristics } & Frequency & Percent \\
\hline Gender: & 192 & 49.4 \\
- Female & 197 & 50.6 \\
- Male & & \\
\hline Age: & 23 & 5.9 \\
- 1 - 25 & 144 & 37.0 \\
- 26 - 30 & 168 & 43.2 \\
- 31 - 35 & 49 & 12.6 \\
- 36 - 40 & 5 & 1.3 \\
- Over 40 & & \\
\hline Educational level: & 23 & 5.8 \\
- Intermediate & 54 & 13.9 \\
- College & 150 & 38.6 \\
- University & 159 & 40.9 \\
- Master & 3 & 0.8 \\
- Other & & \\
\hline Working experience (year): & 31 & 8.0 \\
- 0 - 3 & 102 & 26.2 \\
- 3 - 5 & 129 & 33.2 \\
- - - 10 & 75 & 19.3 \\
- 10 - 15 & 52 & 13.4 \\
- Over 15 & & \\
\hline N = 389 & & \\
\hline
\end{tabular}

Source: Authors' calculation

\subsection{Measurement model}

Analysis of model fit measures shows that CMIN/df $=2.379$, p-value $=0.000, \mathrm{CFI}=$ $0.945, \mathrm{TLI}=0.936, \mathrm{SRMR}=0.0390$ and $\mathrm{RMSEA}=0.060$. These results pass the cut-off values as suggested by $\mathrm{Hu}$ and Bentler (1999). Therefore, our data fit the model well. Table 3 indicates 
that Composite Reliability (CR) of all six latent variables ranges from 0.834 (SSC) to 0.906 (EKS) and Average Variance Extracted (AVE) ranges from 0.560 (SSC) to 0.660 (EKS). This implies that the model achieves convergent validity. In addition, none of the correlations between the construct exceed the square root of the AVE of each construct, implying that all latent variables or constructs receive adequate discriminant validity (Fornell \& Larcker, 1981).

\section{Table 3}

Results of discriminant validity

\begin{tabular}{|c|c|c|c|c|c|c|c|c|c|}
\hline & CR & AVE & MSV & Square root of AVE & TKS & EKS & SSC & RSC & CSC \\
\hline TKS & 0.872 & 0.577 & 0.521 & 0.760 & 1 & & & & \\
\hline EKS & 0.906 & 0.660 & 0.521 & 0.813 & $0.722^{* * *}$ & 1 & & & \\
\hline SSC & 0.834 & 0.560 & 0.361 & 0.748 & $0.388 * * *$ & $0.493 * * *$ & 1 & & \\
\hline RSC & 0.860 & 0.607 & 0.361 & 0.779 & $0.402 * * *$ & $0.512 * * *$ & $0.601 * * *$ & 1 & \\
\hline CSC & 0.864 & 0.614 & 0.490 & 0.784 & $0.700^{* * *}$ & $0.700^{* * *}$ & $0.469 * * *$ & $0.421 * * *$ & 1 \\
\hline
\end{tabular}

***Correlation is significant at the 0.01 level

Source: Authors' calculation

\subsection{Structural model}

An analysis of the structural model is subsequently carried out to verify all proposed hypotheses. The subsequent step involves an estimation that uses maximum likelihood estimation to validate all the hypothesized relationships postulated from the research model (Byrne, 2016). Model fit measures reveal that CMIN/df $=2.379, \mathrm{p}$-value $=0.000, \mathrm{CFI}=0.945$, $\mathrm{TLI}=0.936, \mathrm{SRMR}=0.039, \mathrm{RMSEA}=0.060$. It can be concluded that our data fit the model well, as seen in these results (Hu \& Bentler, 1999). Hypothesis testing was performed and summarised in Table 4. Other than $\mathrm{H} 5$, all remaining hypotheses are statistically significant at different levels.

\section{Table 4}

Hypotheses testing of the structural model

\begin{tabular}{|c|c|c|c|c|}
\hline \multicolumn{2}{|c|}{ Hypothesized relationships } & Proposed effects & SRW & Remark \\
\hline H1 & $\mathrm{SSC} \rightarrow \mathrm{RSC}$ & Positive & $0.517^{* * *}$ & Supported \\
\hline H2 & $\mathrm{SSC} \rightarrow \mathrm{CSC}$ & Positive & $0.469^{* * *}$ & Supported \\
\hline H3 & $\mathrm{CSC} \rightarrow \mathrm{RSC}$ & Positive & $0.179^{* *}$ & Supported \\
\hline H4 & $\mathrm{SSC} \rightarrow \mathrm{EKS}$ & Positive & $0,096^{*}$ & Supported \\
\hline H5 & $\mathrm{SSC} \rightarrow \mathrm{TKS}$ & Positive & $0.012^{\text {ns }}$ & Not supported \\
\hline H6 & $\mathrm{RSC} \rightarrow \mathrm{EKS}$ & Positive & $0.163^{* *}$ & Supported \\
\hline H7 & $\mathrm{RSC} \rightarrow \mathrm{TKS}$ & Positive & $0.125^{* *}$ & Supported \\
\hline $\mathrm{H} 8$ & $\mathrm{CSC} \rightarrow \mathrm{EKS}$ & Positive & $0.300^{* * *}$ & Supported \\
\hline $\mathrm{H} 9$ & $\mathrm{CSC} \rightarrow \mathrm{TKS}$ & Positive & $0.641^{* * *}$ & Supported \\
\hline $\mathrm{H} 10$ & $\mathrm{TKS} \rightarrow \mathrm{EKS}$ & Positive & $0.409^{* * *}$ & Supported \\
\hline
\end{tabular}

Notes: ${ }^{\mathrm{ns}}$ not significant; $* \mathrm{p}<.10 ; * * \mathrm{p}<.05 ; * * * \mathrm{p}<.001$

Source: Authors' calculation 


\subsection{Discussion}

Our study proposes and tests a theoretical model that shapes the connection between social capital and knowledge sharing. Given the increasingly critical role of knowledge sharing as it can contributes to knowledge application, innovation, and eventually performance (Kim \& Lee, 2005; Nonaka \& Taikeuchi, 1995; S. Wang, Noe, \& Wang, 2011), our study provides important evidence regarding how the three social capital dimensions influence both tacit knowledge sharing and explicit knowledge sharing. Theoretically, no attention has been paid to systematically examine how the three social capital dimensions affect knowledge sharing in the public sector. Therefore, our research is a pioneering work contributing significantly to social capital and knowledge-sharing literature. Furthermore, our findings substantially support our hypothesized model. Specifically, all hypothesized relationships were confirmed, except the relationship between structural social capital and tacit knowledge sharing.

In the public sector context, we have asserted that all social capital dimensions are interrelated. Our findings corroborate previous research. Specifically, structural social capital has a favorable influence on relational social capital (Gabarro, 1978; Gulati, 1995; M. Granovetter, 1985). Furthermore, Tsai and Ghosal (1998) showed that social interaction positively influences trustworthiness. At the same time, structural social capital also has a favorable influence on cognitive social capital. The social contacts of organization members have an impact on the establishment of a common vision (Krackhardt, 1990). Furthermore, research on organizational socialization (see, for example, Van Maanen \& Schein, 1979) confirms the critical role of informal social interaction in promoting values learned about organizational norms, as is proven in the findings of Tsai and Ghosal (1998). Finally, the significant relationship between cognitive social capital and relational social capital was consistent with the work of Sitkin and Roth (1993), who contended that trusting relationships originate from value congruence.

In a similar vein, our research results also show that relational social capital and cognitive social capital significantly influence both explicit knowledge sharing and tacit knowledge sharing. This result is completely in agreement with Hau et al. (2013), stating that common beliefs and goals have a favorable impact on sharing explicit knowledge and tacit knowledge. In addition, Zaqout and Abbas (2012) demonstrated the roles of trust in promoting explicit knowledge sharing and tacit knowledge sharing among workers, which is also in line with our findings regarding relational social capital. Several scholars argue that mutual trust between the knowledge-sharing partners is required for the effective transfer of tacit knowledge (Nonaka \& Takeuchi, 1995). However, some say the absence of shared values, vision, and a shared goal can lead to conflict and impede trust, which acts as a barrier to the transfer of tacit knowledge. Additionally, while relational social capital is critical for effective tacit knowledge sharing and explicit knowledge sharing transfer, cognitive social capital also play a critical role in effective tacit knowledge sharing and explicit knowledge sharing transfer. This is consistent with the research conducted by Ganguly et al. (2019) and Zaqout and Abbas (2012).

Interestingly, structural social capital only has a favorable impact on explicit knowledge sharing but has no significant relationship with tacit knowledge sharing. This result is in line with prior studies indicating no favorable effect between structural social capital and tacit knowledge sharing (Ganguly et al., 2019). Additionally, we found that tacit knowledge sharing is positively associated with explicit knowledge sharing. This finding corresponds with the studies mentioned above, including studies done by Cohen and Levinthal (1990), Chumg et al. (2015), Dhanaraj et al. (2004), and Hau et al. (2013). While Cohen and Levinthal (1990) posit that tacit knowledge is necessary to assist in comprehending explicit knowledge, Dhanaraj et al. (2004) 
assert that tacit knowledge can provide the understanding behind explicit procedures in an organization; also, the tacit knowledge learned from workers will assist in learning new explicit routines. Similarly, Hau et al. (2013) found that employees' tacit knowledge-sharing intentions are viewed as if they are sharing a more valuable resource, which can affect their explicit knowledge-sharing intentions. Finally, our findings align with Chumg et al. (2015), stating that it is critical to concentrate on externalizing the knowledge conversion process when creating new explicit knowledge from tacit knowledge in the virtual organization.

\section{Policy implications}

Our work provides several policy implications to create and encourage knowledge sharing by promoting the following dimensions of social capital. As for structural social capital, managers should encourage employees to actively participate in the network of relationships within departments as well as the network of relationships between departments to create and facilitate knowledge transfer.

To promote relational social capital, managers should allocate more resources in building trust and enhancing cooperation among cadres and civil servants within and between departments. To develop and nurture trust, it is necessary to create a truly open and consistent working atmosphere. To promote collaboration at work, managers need to focus on and create favorable conditions for the working environment, facilities, equipment, and working facilities for employees. The more trust employees have the more knowledge they can share and benefit each other.

To promote cognitive social capital, managers are responsible for establishing the organization's vision and communicating it to all employees to encourage collaboration to enhance knowledge sharing. Public organizations need to build organizational culture, create consensus and cohesion among members of the organization so that everyone has a voice, and promotes ideas and initiatives in building visions and goals. This, in turn, inspires them to overcome difficulties and challenges to achieve effective work performance.

\section{Limitations and future research}

This work also has several limitations. First, this research has not analyzed and tested the role of control variables, for example, age, gender, educational level or experience. Future research should add these control variables in the analysis to better understand the possible differences in these variables that may be useful policy implications.

Second, our study uses cross-sectional data, which only collects data at one single point of time to examine the link between social capital and knowledge sharing. Future research may use a longitudinal design to examine the possible changes over time to have better insights into more in-depth factors that may affect knowledge sharing in the public sector.

Third, our study develops a theoretical model and only focuses on the public sector. Future research may expand the context to include other sectors, such as the business sector, to provide a complete view of social capital and knowledge sharing.

\section{References}

Adler, P. S., \& Kwon, S. W. (2002). Social capital: Prospects for a new concept. Academy of Management Review, 27(1), 17-40.

Alavi, M., \& Leidner, D. E. (2001). Knowledge management and knowledge management systems: Conceptual foundations and research issues. MIS Quarterly, 25(1), 107-136. 
Amayah, A. (2013). Determinants of knowledge sharing in a public sector organization. Journal of Knowledge Management, 17(3), 454-471.

Anderson, J. C., \& Gerbing, D. W. (1988). Structural equation modeling in practice: A review and recommended two-step approach. Psychological Bulletin, 103(3), 411-423.

Arbuckle, J. L. (2016). IBM SPSS AMOS 24 User's guide. New York, NY: IBM Corp.

Barher, B. (1983). The logic and limits of trust. New Brunswick, NJ: Rutgers University Press.

Borgatti, S. P., \& Cross, R. (2003). A relational view of information seeking and learning in social networks. Management Science, 49(4), 432-445.

Byrne, B. M. (2016). Structural equation modeling with Amos: Basic concepts, applications, and programming (3rd ed.). NewYork, NY: Routledge/Taylor \& Francis Group.

Chow, W. S., \& Chan, L. S. (2008). Social network, social trust and shared goals in organizational knowledge sharing. Information \& Management, 45(7), 458-465.

Chumg, H. F., Cooke, L., Fry, J., \& Hung, I. H. (2015). Factors affecting knowledge sharing in the virtual organisation: Employees' sense of well-being as a mediating effect. Computers in Human Behavior, 44(C), 70-80.

Cohen, W. M., \& Levinthal, D. A. (1990). Absorptive capacity: A new perspective on learning and innovation. Administrative Science Quarterly, 35(1), 128-152.

Dhanaraj, C., Lyles, M. A., Steensma, H. K., \& Tihanyi, L. (2004). Managing tacit and explicit knowledge transfer in IJVs: The role of relational embeddedness and the impact on performance. Journal of International Business Studies, 35(5), 428-442.

Dyer, J. H., \& Nobeoka, K. (2000). Creating and managing a high-performance knowledgesharing network: The Toyota case. Strategic Management Journal, 21(3), 345-367.

Foos, T., Schum, G., \& Rothenberg, S. (2006). Tacit knowledge transfer and the knowledge disconnect. Journal of Knowledge Management, 10(1), 6-18.

Fornell, C., \& Larcker, D. F. (1981). Evaluating structural equation models with unobservable variables and measurement error. Journal of Marketing Research, 18(1), 39-50.

Gabarro, J. J. (1978). The development of trust, influence, and expectations. In A. G. Athos \& J. J. Gabarro (Eds.), Interpersonal behaviors: Communication and understanding in relationships (pp. 290-303). Englewood Cliffs, NJ: Prentice-Hall.

Ganguly, A., Talukdar, A., \& Chatterjee, D. (2019). Evaluating the role of social capital, tacit knowledge sharing, knowledge quality and reciprocity in determining innovation capability of an organization. Journal of Knowledge Management, 23(6), 1105-1135.

Granovetter, M. S. (1973). The strength of weak ties. American Journal of Sociology, 78(6), 1360-1380.

Granovetter, M. (1985). Economic action and social structure: The problem of embeddedness. American Journal of Sociology, 91(3), 481-510.

Gulati, R. (1995). Does familiarity breed trust? The implications of repeated ties for contractual choice in alliances. Academy of Management Journal, 38(1), 85-112.

Hair, J. F., Black, W. C., Babin, B. J., \& Anderson, R. E. (2014). Multivariate data analysis. Edinburgh Gate, UK: Pearson New International Edition. 
Hau, Y. S., Kim, B., Lee, H., \& Kim, Y. G. (2013). The effects of individual motivations and social capital on employees' tacit and explicit knowledge sharing intentions. International Journal of Information Management, 33(2), 356-366.

Hlupic, V., Pouloudi, A., \& Rzevski, G. (2002). Towards an integrated approach to knowledge management: 'Hard', 'soft' and 'abstract' issues. Knowledge and Process Management, 9(2), 90-102.

Hu, L. T., \& Bentler, P. M. (1999). Cutoff criteria for fit indexes in covariance structure analysis: Conventional criteria versus new alternatives. Structural Equation Modeling: A Multidisciplinary Journal, 6(1), 1-55.

Inkpen, A. C., \& Tsang, E. W. (2005). Social capital, networks, and knowledge transfer. Academy of Management Review, 30(1), 146-165.

Kim, S., \& Lee, H. (2005). Employee knowledge sharing capabilities in public \& private organizations: Does organizational context matter? Proceedings of the 38th Hawaii International Conference on System Sciences, 8, 249-258.

Kim, T., \& Lee, G. (2010). Examining social capital and knowledge sharing as antecedents of service innovativeness and business performance in the hotel industry: An application of the Resource-Based View (RBV) theory. Journal of Tourism Sciences, 34(7), 13-36.

Kline, R. B. (2015). Principles and practice of structural equation modeling. New York, NY: The Guilford Press.

Kogut, B., \& Zander, U. (1996). What firms do? Coordination, identity, and learning. Organization Science, 7(5), 502-518.

Krackhardt, D. (1990). Assessing the political landscape: Structure, cognition, and power in organizations. Administrative Science Quarterly, 35(2), 342-369.

Levin, D. Z., \& Cross, R. (2004). The strength of weak ties you can trust: The mediating role of trust in effective knowledge transfer. Management Science, 50(11), 1477-1490.

Luen, T. W., \& Al-Hawamdeh, S. (2001). Knowledge management in the public sector: Principles and practices in police work. Journal of Information Science, 27(5), 311-318.

Miller, N. J., Besser, T., \& Malshe, A. (2007). Strategic networking among small businesses in small US communities. International Small Business Journal, 25(6), 631-665.

Nahapiet, J., \& Ghoshal, S. (1998). Social capital, intellectual capital, and the organizational advantage. Academy of Management Review, 23(2), 242-266.

Nonaka, I. (1991). The knowledge creating company. Harvard Business Review, 69(6), 96-104.

Nonaka, I. (1994). A dynamic theory of organizational knowledge creation. Organization Science, 5(1), 14-37.

Nonaka, I., \& Takeuchi, H. (1995). The knowledge-creating company. New York, NY: Oxford University Press.

Ouchi, W. G. (1980). Markets, bureaucracies, and clans. Administrative Science Quarterly, 25(1), 129-141.

Pentland, B. T. (1995). Grammatical models of organizational processes. Organization Science, 6(5), 541-556. 
Reagans, R., \& McEvily, B. (2003). Network structure and knowledge transfer: The effects of cohesion and range. Administrative Science Quarterly, 48(2), 240-267.

Reychav, I., \& Weisberg, J. (2009). Bridging intention and behavior of knowledge sharing. Journal of Knowledge Management, 14(2), 285-300.

Sitkin, S. B., \& Roth, N. L. (1993). Explaining the limited effectiveness of legalistic "remedies" for trust/distrust. Organization Science, 4(3), 367-392.

Tsai, W., \& Ghoshal, S. (1998). Social capital and value creation: The role of intrafirm networks. Academy of Management Journal, 41(4), 464-476.

Van den Hooff, B., \& Huysman, M. (2009). Managing knowledge sharing: Emergent and engineering approaches. Information \&Management, 46(1), 1-8.

Van Maanen, J., \& Schein, E. H. (1979). Toward a theory of organizational socialization. In B. M. Staw (Ed.), Research in organizational behavior (pp. 209-264). Greenwich, CT: JAI Press.

Wang, Z., \& Wang, N. (2012). Knowledge sharing, innovation and firm performance. Expert Systems with Applications, 39(10), 8899-8908.

Wang, S., Noe, R. A., \& Wang, Z. M. (2011). Motivating knowledge sharing in knowledge management systems: A quasi-field experiment. Journal of Management, 40(4), 978-1009. doi:10.1177/0149206311412192

Wasko, M. M., \& Faraj, S. (2005). Why should I share? Examining social capital and knowledge contribution in electronic networks of practice. MIS Quarterly, 29(1), 35-57.

Willem, A., \& Buelens, M. (2007). Knowledge sharing in public sector organizations: The effect of organizational characteristics on interdepartmental knowledge sharing. Journal of Public Administration Research and Theory, 17(4), 581-606.

Zaqout, F., \& Abbas, M. (2012). Towards a model for understanding the influence of the factors that stimulate university students' engagement and performance in knowledge sharing. Library Review, 61(5), 345-361. 